九州大学学術情報リポジトリ

Kyushu University Institutional Repository

\title{
High Tributyltin Contamination in Sediments from Ports in Indonesia and Northern Kyushu, Japan
}

Undap, Suzanne Lydia

Faculty of Fisheries and Marine Sciences, Sam Ratulangi University

Nirmala, Kukuh

Faculty of Fisheries and Marine Science, Bogor Agricultural University

Miki, Shizuho

Laboratory of Marine Environmental Science, Faculty of Agriculture, Kyushu University

Inoue, Suguru

Laboratory of Marine Environmental Science, Faculty of Agriculture, Kyushu University

他

https://doi.org/10.5109/26172

出版情報：九州大学大学院農学研究院紀要. 58 (1)，pp.131-135，2013-02. Faculty of Agriculture， Kyushu University

バージョン :

権利関係 : 


\title{
High Tributyltin Contamination in Sediments from Ports in Indonesia and Northern Kyushu, Japan
}

\section{Suzanne Lydia UNDAP ${ }^{1,2}$, Kukuh NIRMALA ${ }^{3}$, Shizuho MIKI ${ }^{1}$, Suguru INOUE, Xuchun QIU ${ }^{1}$, Masato HONDA ${ }^{1}$, Yohei SHIMASAKI ${ }^{1}$ and Yuji OSHIMA ${ }^{1, *}$}

\author{
Laboratory of Marine Environmental Science, Faculty of Agriculture, Kyushu University, \\ Hakozaki 6-10-1, Higashi-ku, Fukuoka, 812-8581, Japan \\ (Received October 26, 2012 and accepted November 8, 2012)
}

\begin{abstract}
Sediment samples were collected from 20 stations in the port areas around three cities (Jakarta, Bali and Manado) in Indonesia in 2011 and from 9 stations in the port areas in northern Kyushu, Japan in 2010. High concentrations of tributyltin (TBT) were found in sediments collected in front of the shipyard in Bitung port, Manado $(4.25 \mu \mathrm{g} / \mathrm{g}$ wet weight) and in Benoa port, Bali $(0.21 \mu \mathrm{g} / \mathrm{g}$ wet weight). High TBT concentrations were also detected in sediments from next to the shipyard in Hakata port ( $0.63 \mu \mathrm{g} / \mathrm{g}$ wet weight), Fukuoka, Japan. These results suggest that ports might be major sources of TBT pollution in Indonesia and Japan, even though TBT usage has been regulated in Japan since 1990.
\end{abstract}

Key words: hot spot, port, pollution, sediment, tributyltin

\section{INTRODUCTION}

Tributyltin (TBT) has been widely used as an antifouling agent in marine environments since the early 1960s (Hugget et al., 1992), having been applied to boat hulls and to marine aquaculture equipment. Because of its high toxicity of TBT to aquatic organisms (Clark et al., 1988), the use of TBT has been regulated worldwide since the 1980s. The International Maritime Organization (IMO) imposed a worldwide ban on TBT in 2003 (Champ, 2000). However, TBT is still detected in coastal sediments in the world (Antizar-Ladislao, 2008). Around northern Kyushu, Japan, the concentrations of TBT have been found to range from 0.005 to $0.094 \mu \mathrm{g} / \mathrm{L}$ and 0.007 to $1.1 \mu \mathrm{g} / \mathrm{g}$ dry weight (dw) in seawater and sediments, respectively (Inoue et al., 2002), from 0.008 to $0.135 \mu \mathrm{g} / \mathrm{g}$ in bivalves (Inoue et al., 2006), and from 0.0014 to $0.19 \mu \mathrm{g} / \mathrm{mL}$ in blood from marine fish (Miki et al., 2011). Contamination of sediment and aquatic organism by TBT still occurred in coastal areas around northern Kyushu. These results suggest the existence of TBT hotspots that continue to release TBT into the wider environment.

The Indonesian archipelago consists of many islands, and, by area, is 75\% water. Many people in Indonesia use boats, and boats are suspected of being a major source of TBT contamination. The use of TBT is not yet regulated in Indonesia, even though contamination of the Indonesian environment by butyltin compounds has been reported (Sudaryanto et al., 2005; Midorikawa et al., 2004). Total butyltin concentrations in sediments (dw), bivalves wet weight (ww), and fish (ww) of 0.023-

1 Laboratory of Marine Environmental Science, Faculty of Agriculture, Kyushu University, Hakozaki 6-10-1, Higashiku, Fukuoka, 812-8581, Japan

2 Faculty of Fisheries and Marine Sciences, Sam Ratulangi University - Manado, Indonesia

${ }^{3}$ Faculty of Fisheries and Marine Science, Bogor Agricultural University - Bogor, Indonesia.

* Corresponding author (E-mail: yoshima@agr.kyushu-u.ac.jp)
$0.32 \mu \mathrm{g} / \mathrm{g}, \quad 0.005-0.064 \mu \mathrm{g} / \mathrm{g}, \quad 0.00041-0.019 \mu \mathrm{g} / \mathrm{g}$ and $0.209-0.425 \mu \mathrm{g} / \mathrm{g}$ have been found in the major harbors of Jakarta, Surabaya, Medan and Bitung Manado respectively (Rumengan et al., 2008; Harino et al., 2012). Shipyards are suspected of being hot spots in ports and harbors. Extremely high TBT concentrations (2837 $\mu \mathrm{g} /$ $\mathrm{kg} \mathrm{dw}$ ) were detected in surface sediment collected from Hong Kong port (Cheung et al., 2003) and a Sn concentration of $36.3 \mu \mathrm{g} / \mathrm{g}$ was found at a site in front of a dry dock and near surface runoff drainage point in a Korean shipyard (Kim et al., 2011). There is currently little information on TBT concentrations in sediments in and near Indonesian shipyards.

In this study, we measured TBT concentrations in sediments collected from ports in Indonesia, where no regulations for the use of TBT and dibutyltin (DBT) have been implemented, and in sediments from ports in Japan, where TBT usage has been regulated since 1990.

\section{MATERIALS AND METHODS}

\section{Sediment sampling}

Three areas of Indonesia, Manado, Bali and Jakarta were selected as sampling areas, and samples were collected in January 2011. The sampling sites in the north of Sulawesi Island were Manado port (Fig. 1A, Stations 1-3), marina in Manado port (Fig. 1A, Stations 4) and Bitung port (Fig. 1B, Stations 5-8). The sampling sites on Bali Island were in Benoa port (near Denpasar) (Fig. 1C, Stations 9-11). The sampling sites on Java Island were in Jakarta Bay, and Tanjung Priok port (Fig. 1D, Stations 12-14), marina in Ancol (Fig. 1D, Stations 15-17) and Sunda Kelapa port (Fig. 1D, Stations 18-20). Sediment samples ( $5 \mathrm{~cm}$ deep) were collected using an Eckman grab sampler (Rickly hydrological company, Mississippi, US). Samples from each site were pooled and stones were removed. The samples were subsequently transferred to $50 \mathrm{~mL}$ polyethylene tubes and kept at $-30^{\circ} \mathrm{C}$ during transportation. Japanese sediment sam- 
ples were collected from Hakata port in Hakata Bay (Fig. 1E, Stations 21-23) and Imari port, Imari bay (Fig. 1F, Stations 24-29) in September 2010. These sediment samples ( $5 \mathrm{~cm}$ deep) were collected using a core sampler (Gravity Core Sampler, Rigo-sha, Tokyo, Japan) and stored at $-30^{\circ} \mathrm{C}$.

\section{Reagents}

Tributyltin chloride- $\mathrm{d}_{27}\left(\mathrm{TBTCl}-\mathrm{d}_{27}\right)$ and dibutyltin chloride $-\mathrm{d}_{18}\left(\right.$ DBTCl$\left.-\mathrm{d}_{18}\right)$, used as internal standards, were purchased from Hayashi Pure Chemical Industries, Ltd. (Osaka, Japan). Sodium tetraethyl borate [(NaB $\left.\left(\mathrm{C}_{2} \mathrm{H}_{5}\right)_{4}\right)$ ] and Florisil were obtained from Wako Pure Chemical Industries, Ltd. (Osaka, Japan). All organic solvents were of pesticide residue analytical grade. Other reagents used were of analytical grade.

\section{Analytical procedure for butyltin}

The concentrations of butyltin compounds in the samples were analyzed following the method published by Iwamura et al., (2000) with slight modifications. After washing all glassware with hexane and acetone, $1 \mathrm{~g}$ of each sample was spiked with $1 \mu \mathrm{g}$ each of the TBTCl- $\mathrm{d}_{27}$ and $\mathrm{DBTCl}-\mathrm{d}_{18}$ internal standards, in a centrifuge tube. Then $10 \mathrm{~mL}$ of a 1:1:1 mixture of $1 \mathrm{M}$ hydrobromic acid in methanol, ethyl acetate and deionized water was added. The tube was shaken for $30 \mathrm{~min}$, and then centrifuged for $5 \mathrm{~min}$ at $3000 \mathrm{rpm}$ about $1500 \times \mathrm{g}$ in our centrifugation. The supernatant solution was separated and the sample was extracted twice with $10 \mathrm{~mL}$ of $3: 2$ ethyl acetate:hexane solution, with 10 min shaking followed by centrifuging for each extraction. The organic layers obtained were concentrated using a Turbo Vap II (Zymark, Hopkinton, MA, USA) with $\mathrm{N}_{2}$ gas flushing at $35^{\circ} \mathrm{C}$, to 1 $\mathrm{mL}$ and made up to $10 \mathrm{~mL}$ with hexane. The sample was ethylated by adding $0.5 \mathrm{~mL}$ of a $5 \%$ sodium tetraethyl borate solution, to derivatize the target organotin compounds, and $10 \mathrm{~mL}$ of deionized water was added. The mixture was then shaken for $30 \mathrm{~min}$. $10 \mathrm{~mL}$ of $1 \mathrm{M}$ potassium hydroxide solution was added, to saponify any fat, and the sample was shaken for $60 \mathrm{~min}$, then centrifuged at $3000 \mathrm{rpm}$ for $5 \mathrm{~min}$. The hexane layer was collected by pipette and concentrated before being cleaned up using a Florisil-packed chromatography column, with the organotin compounds being eluted with hexane. The resulting solution was concentrated again using the Turbo Vap II.

Butyltin concentrations were measured using an Agilent 6890 gas chromatograph (GC) (Avondale, PA, USA) equipped with an Agilent 5973 mass spectrometer (MS) operated in El+ mode. The GC column was a $30 \mathrm{~m}$ $0.21 \mathrm{~mm}$ id fused silica capillary column (HP-5MS, Agilent J \& W, CA, US). The carrier gas was helium (Zero-U grade; flow rate: $1.2 \mathrm{~mL} / \mathrm{min}$ ). The GC temperature program was: $60^{\circ} \mathrm{C}$ for $2 \mathrm{~min}, 20^{\circ} \mathrm{C} / \mathrm{min}$ to $130^{\circ} \mathrm{C}$, $10^{\circ} \mathrm{C} / \mathrm{min}$ to $210^{\circ} \mathrm{C}, 5^{\circ} \mathrm{C} / \mathrm{min}$ to $260^{\circ} \mathrm{C}$, then $10^{\circ} \mathrm{C} / \mathrm{min}$ to $300^{\circ} \mathrm{C}$ (held for $2 \mathrm{~min}$ ). The injector, interface, and ion source temperature were $270^{\circ} \mathrm{C}, 280^{\circ} \mathrm{C}$, and $230^{\circ} \mathrm{C}$, respectively. The ionization voltage was $70 \mathrm{eV}$. Ions of DBT, DBTCl- $\mathrm{d}_{18}$, TBT and TBTC1- $\mathrm{d}_{27}$ ions were moni- tored at $\mathrm{m} / \mathrm{z}$ of $261,279,263$ and 318 , respectively.

The accuracy of the TBT and DBT analysis technique was checked using the certified reference materials (CRMs) NIES-CRM No.11 (fish tissue) and NIES-CRM No.12 (marine sediment) (National Institute for Environmental Studies, Tsukuba, Japan). The butyltin concentrations were calculated from the ratio between the butyltin peak and the appropriate butyltin $\mathrm{Cl}$ internal standard peak areas, and are expressed as $\mu \mathrm{g} / \mathrm{g}$ wet weight (ww). All samples were analyzed in triplicate. A TBT recovery test was performed $(n=3)$ with sediment samples containing an undetectable level of TBT spiked with $1 \mu \mathrm{g}$ of TBTCl.

The TBT concentrations detected in the CRMs were $1.17 \mu \mathrm{g} / \mathrm{g}$ in NIES-CRM No. 11 (certified concentration $1.3 \mu \mathrm{g} / \mathrm{g}$ ) and $0.16 \mu \mathrm{g} / \mathrm{g}$ in NIES-CRM No.12 (certified concentration $0.19 \mu \mathrm{g} / \mathrm{g}$ ). Therefore, we concluded that our detected TBT concentrations agreed with the NIES-CRM certified concentrations.

\section{RESULTS}

TBT and DBT were detected in the sediment samples from all 20 stations in Indonesia (Manado, Bali, Jakarta, Fig. 1A-D) with TBT concentrations of $0.007-4.25 \mu \mathrm{g} / \mathrm{g}$ ww and DBT concentrations between 0.009 to $1.74 \mu \mathrm{g} / \mathrm{g}$ ww. In the Jakarta Bay samples (Fig. 1D), the highest TBT concentration was found in a sample taken from marina in Ancol (Station 16, $0.33 \mu \mathrm{g} / \mathrm{g} \mathrm{ww}$ ), and the next highest concentration was found in a sample from close to the shipyard in Tanjung Priok port (Station 13, $0.32 \mu \mathrm{g} / \mathrm{g}$ ww). Low TBT concentrations were detected in samples from the other sampling sites. TBT was found at concentrations between $0.007-0.015 \mu \mathrm{g} / \mathrm{g}$ ww in samples from Sunda Kelapa port. (Fig. 1D, Stations 18-20), where DBT concentrations were higher than TBT concentrations. The highest TBT concentration ( $0.21 \mu \mathrm{g} / \mathrm{g}$ ww) in the Benoa port, Bali (Fig. 1D) area was found at Station 10 , which is very closed to the shipyard.

The highest TBT concentrations in the Manado area samples were found in samples from Bitung port ( $4.25 \mu \mathrm{g} / \mathrm{g} w \mathrm{w}$, Fig. 1 B, Station 7, followed by Station 6, $3.44 \mu \mathrm{g} / \mathrm{g}$ ww), these were close to the shipyard. Low TBT concentrations were found at the other Manado sampling sites. TBT was found at just $0.04 \mu \mathrm{g} / \mathrm{g}$ ww in a sample from Station 3 in Manado port (Fig. 1 A).

The highest TBT concentration found in the Japanese samples was from sediment collected from Station 23 $(0.63 \mu \mathrm{g} / \mathrm{g} w \mathrm{w})$, which is located closed to the shipyard in Hakata port, and the next highest concentration was in sediment from Station $21(0.49 \mu \mathrm{g} / \mathrm{g} \mathrm{ww})$. TBT and DBT were not detected $(<0.005 \mu \mathrm{g} / \mathrm{g})$ at Station 22 . The highest DBT concentration in the Japanese samples $(0.21 \mu \mathrm{g} / \mathrm{g} w w)$ was also found at station 21 , and next highest was found at Station $23(0.08 \mu \mathrm{g} / \mathrm{g} w w)$. TBT and DBT were only detected in Imari port at Station 28, which is located in front of the shipyard, with a TBT concentration of $0.06 \mu \mathrm{g} / \mathrm{g}$ ww and a DBT concentration of $0.02 \mu \mathrm{g} / \mathrm{g}$ ww, TBT and DBT were not detected $(<0.005 \mu \mathrm{g} / \mathrm{g})$ at Station 27. 


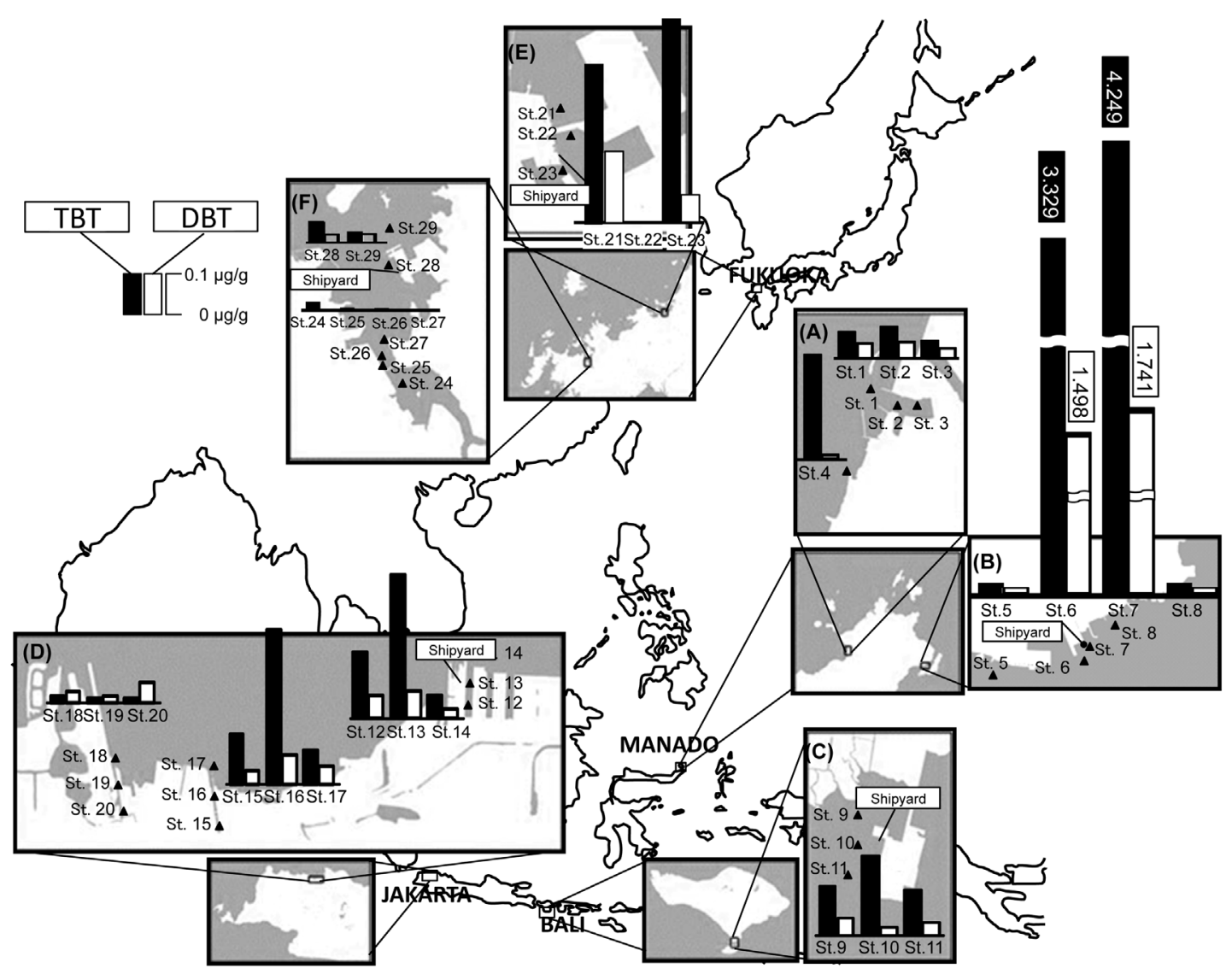

Figure 1. Map showing sample site locations and the concentrations of butyltin (TBT and DBT) in sediment samples from Indonesia [(A) Manado port, (B) Bitung port, (C) Benoa port, Bali and (D) Tanjung Priok port, Marina in Ancol, Sunda Kelapa port] and Fukuoka, Japan [(E) Hakata port, (F) Imari port].

\section{DISCUSSION}

High TBT concentrations were detected in sediment samples collected from ports in Indonesia and Japan. These results suggest that ports might be major sources of TBT pollution in both Indonesia and Japan, even though TBT usage has been regulated in Japan since 1990.

The highest TBT and DBT concentrations in the Indonesia samples were found in Bitung port, Manado, in north Sulawesi, which is the fourth biggest port in Indonesia.

Imposex symptoms have been found in biota from coastal areas of the island of Ambon (eastern Indonesia), and were presumed to have been caused by TBT compounds leaching from the anti-fouling paints used on boat hulls (Ellis et al., 1990; Evans et al., 1995). Sudaryanto et al., (2005) and Rumengan et al., (2008) reported that in sediments from Indonesia the total butyltins (TBT, DBT and monobutyltin) concentrations ranged from 0.51 to $320 \mathrm{ng} / \mathrm{g} \mathrm{dw}$ in 1998 . The TBT concentrations we found in this study were higher than above reported concentrations in samples from Indonesia. Our data suggest that TBT contamination is still occurring in Indonesia. It is worth noting that the sediments from the shipyards in ports are periodically discharged into the sea, which could result in widespread contamination in the coastal areas of Indonesia. Butyltins has been identified as a contaminant of potential concern in the marine sediment (Rumengan et al., 2008).

Arai and Harino (2009) reported lower butyltin residue concentrations in Indonesia than have been reported in coastal and harbor areas in other parts of the world including several other developing Asian countries and urbanized industrial nations such as the USA, European countries, Australia and Japan. However, our study, performed in 2011, show that there are high butyltin concentrations in sediments in Indonesia. These results confirmed that, with no current restrictions, there is a high risk of heavy butyltin contamination in the marine of Indonesia.

A high concentration of TBT $(0.63 \mu \mathrm{g} / \mathrm{g}$ ww) was detected in Hakata port, Japan, which suggests either a fresh input of TBT into the environment or only slow degradation processes in this region. TBT concentrations in sediment in Japan have decreased, but TBT is still detected even though the use of TBT in Japan has been strictly regulated since 1990 .

TBT concentrations were lower in sediments from Japan than in sediments from Indonesia. There appears 
Table 1. Concentrations of DBT and TBT ( $\mu \mathrm{g} / \mathrm{g}$ dry weight) in sediments collected around the world * wet weight; na=no data available; nd=not detected

\begin{tabular}{|c|c|c|c|c|c|}
\hline Location & Area description & Sampling year & DBT & TBT & References \\
\hline China & Xiamen port & 2002 & nd & 0.077 & Huang et al., 2005 \\
\hline Hawaii & Pearl Harbor & Published 1989 & $0.004-0.367$ & $0.004-2.83$ & Kram et al., 1989 \\
\hline Hong kong & Harbour & 2002 & na & $<0.0001-0.56$ & Cheung et al., 2003 \\
\hline India & $\begin{array}{l}\text { Ship building, ship repair, } \\
\text { dry dock and small jetties }\end{array}$ & 2000-2002 & $\begin{array}{l}\text { nd-0.469; } \\
\text { nd-0.131 }\end{array}$ & $\begin{array}{l}0.016-16.816 \\
0.0045-1.193\end{array}$ & Bhosle et al., 2006 \\
\hline Indonesia & $\begin{array}{l}\text { Port, urban and industrial } \\
\text { area }\end{array}$ & 1998 & $<0.0027-0.087$ & $0.00051-0.19$ & Sudaryanto et al., 2005 \\
\hline Indonesia & $\begin{array}{l}\text { Manado, Bitung port, } \\
\text { Gangga Island \& Jakarta } \\
\text { Bay }\end{array}$ & 2004 & $0.0019-0.012$ & $0.0007-0.35$ & Harino et al., 2012 \\
\hline Indonesia & Port \& shipyard & 2011 & nd-1.74 & $\mathrm{nd}-4.25$ & This study* \\
\hline Japan & Otsuchi Bay & 1996 & na & $0.01-0.64$ & Harino et al., 1998 \\
\hline Japan & Port of Osaka & 1995-1996 & na & $0.01-2.1$ & Harino et al., 1998 \\
\hline Japan & Maizuru Bay & 2003 & $0.0023-0.023$ & $0.0012-0.019$ & Ohji et al., 2007 \\
\hline Japan & Hiroshima Bay & $2003-2004$ & $0.0013-0.14$ & $0.0012-0.17$ & Onduka et al., 2008 \\
\hline Japan & Hakata Port, & 1998 & na & 1.1 & Inoue et al., 2002 \\
\hline Japan & Port \& shipyard & 2010 & nd-0.214 & nd-0.631 & This study* \\
\hline Korea & Enclosed bay & 1995 & $0.01-0.573$ & $0.004-0.382$ & Shim et al., 1999 \\
\hline Malaysia & $\begin{array}{l}\text { Area of urban, aquacul- } \\
\text { ture, industrial, shipping } \\
\text { line and Port }\end{array}$ & $1997-1998$ & $0.0038-0.31$ & $0.0028-1.1$ & Sudaryanto et al., 2004 \\
\hline Thailand & Coastal area & 1995 & $0.0002-1.9$ & $0.004-4.5$ & $\begin{array}{l}\text { Kan-Atireklap et al., } 1997 \\
\text { Harino et al., } 2006\end{array}$ \\
\hline Thailand & Industrial area & 2004 & $0.001-0.368$ & $0.002-1.246$ & Midorikawa et al., 2004 \\
\hline Vietnam & $\begin{array}{l}\text { North \& central coastal } \\
\text { areas }\end{array}$ & 2002 & $0.00064-0.0046$ & $0.00089-0.034$ & \\
\hline
\end{tabular}

to be an increasing TBT concentration trend in sediment in Indonesia from 1998 (Sudaryanto et al., 2005; Rumengan et al., 2008; Harino et al., 2012) to 2011 (our results). In contrast, a decreasing trend was observed in TBT sediment concentrations from 1998 (Inoue et al., 2006) to 2010 (our results) in northern Kyushu, Japan. The difference in TBT and DBT concentrations and trends is likely to be related to the fact that these compounds have been banned in Japan, whereas no regulations on their use have been implemented in Indonesia.

TBT contamination trends are shown in Table 1, in which the concentrations of butyltin in various parts of the world are compared with the data from our study. High concentrations of TBT were found in a coastal area in Malaysia (1.1 $\mu \mathrm{g} / \mathrm{g}$ dw; Sudaryanto et al., 2004), in an industrial area where many tankers and cargo ship in Thailand (1.25 $\mu \mathrm{g} / \mathrm{g} \mathrm{dw}$ ) (Harino et al., 2006) and in Kochi (16.82 $\mu \mathrm{g} / \mathrm{g} \mathrm{dw}$ ) and Mumbai (1.19 $\mu \mathrm{g} / \mathrm{g}$ dw) harbors in India (Bhosle et al., 2006). Harbors area, of course, the busiest part of port areas, and often include ship building, ship repair, and dry dock facilities, together with small jetties for berthing fishing boats. The highest TBT concentration found in sediment (12.4 $\mu \mathrm{g} / \mathrm{g} \mathrm{dw})$ was associated with shipyard activity (Page et al., 1995). In our study, the highest TBT concentration $(4.25 \mu \mathrm{g} / \mathrm{g}$ ww) was also recorded in sediment collected from a shipyards area. This trend is consistent with the sediments being highly affected by shipping activities, and shipyards being mostly responsible for the TBT and DBT contamination in the ports.

High TBT concentrations were found in specific areas in Indonesia and the northern Kyushu coastline, particu- larly in sediments near shipyard. Contaminated wastes and wastewater from the ports are important potential sources of TBT pollution. There are many potential present and future sources of TBT contamination to the marine environment. Our results suggest that shipyards areas in ports may be major sources. Adverse effects on non-target biota are possible because sediment re-suspension can release TBT into the water column (Harris et al., 1991; Page et al., 1995).

\section{CONCLUSIONS}

High TBT concentrations were found in sediment samples collected near and in front of ports in Japan and Indonesia. Our results support the supposition that shipyard activities are major sources of TBT pollution in Indonesia and Japan, even though TBT usage has been regulated in Japan since 1990.

\section{ACKNOWLEDGMENTS}

The authors wish to acknowledge the financial support provided for this work as a scholarship from the Directorate General for Higher Education, Indonesian Ministry of Education and Culture through the Department of Aquatic Management Resources, Sam Ratulangi University (UNSRAT) Manado, Indonesia.

\section{REFERENCES}

Antizar-Ladislao, B. 2008 Environmental levels, toxicity and human exposure to tributyltin (TBT)-contaminated marine 
environment. A review. Environ. Int., 34: 292-308

Arai, T. and H. Harino 2009 Contamination by organotin compounds in Asia. In "Ecotoxicology of Antifouling Biocides", ed. by T. Arai, H. Harino, M. Ohji and W.J. Langston, Springer Japan, Tokyo, pp. 61-74

Bhosle, N. B., A. Garg, R. Harji, S. Jadhav, S.S. Sawan, V. Krishnamurthy, and C. Anil 2006 Butyltin in the sediments of Kochi and Mumbai harbours, west coast of India. Environ. International., 32: 252-258

Champ, M, A. 2000 A review of organotin regulatory strategies, pending actions, related costs and benefits. J. Sci. Total Environ., 258: 21-71

Clark, E. A., R. M. Sterrit and J. N. Lester 1988 The fate of tributyltin in the aquatic environment. J. Environ. Sci. Technol., 22: 600-604

Cheung, K. C., M. H. Wong and Y. K Yung 2003 Toxicity assessment of sediments containing tributyltin around Hong Kong Harbour. J. Toxicol Lett., 137: 121-131

Ellis, D. V. and L. A. Pattisina 1990 Widespread neogastropod imposex: A biological indicator of global TBT contamination? Marine Poll. Bullet., 21: 248-253

Evans, S. M., M. Dawson, J. Day, C. L. J. Frid, M. E. Gill, A. Pattisina and J. Porter 1995 Domestic waste and TBT pollution in coastal areas of Ambon Island (Eastern Indonesia). Marine Poll. Bullet., 30: 109-115

Harris, J. R. W., C. C. Hamlin and A. R. D. Stebbing ARD 1991 A stimulation study of the effectiveness of legislation and improved dockyard practice in reducing TBT concentration in the Tamar Estuary. Marine Environ Research., 32: 279-292

Huggett, R. J., M. A. Unger, P. F. Seligman and A. O. Valkirs 1992 The marine biocide tributyltin. Environ. Sci. Technol., 26: $232-237$

Harino, H., M. Fukushima, Y. Yamamoto, S. Kawai and N. Miyazaki 1998 Contamination of butyltin and phenyltin compounds in the marine environment of Otsuchi Bay, Japan. Environ. Poll., 101: $209-214$

Harino, H., M. Ohji, G. Wattayakorn, T. Arai, S. Rungsupa and N. Miyazaki 2006 Occurrence of antifouling biocides in sediment and green mussels from Thailand. Arch. Environ. Contam. Toxicol., 51: 400-407

Harino, H., S. Eguchi, Y. Yamamoto, Y. Kurokawa, S. Kawai, T. Arai, M. Ohji, S. Yamato, N. Kobayashi and N. Miyazaki 2008 Distribution of organotin compounds in representative coastal areas from Japan: a review. J. Coastal Marine Science., 32(1): 88-95

Harino, H., Z. Arifin, F. M. I. Rumengan, T. Arai, Ohji M and N. Miyazaki 2012 Distribution of antifouling biocides and perfluoroalkyl compounds in sediments from selected locations in Indonesia coastal waters. Arch. Environ. Contam. Toxicol., 63: $13-21$

Iwamura, T., K. Kadokami, D. Jin-ya and K. Tanada 2000 Determination of organotin compounds in biological samples using ethyl derivatization and GC/MS. Bunseki Kagaku The Japan society for anal. Chem., 49(7): 523-528 (in Japanese with English abstract)

Inoue, S., Y. Oshima, N. Imada and T. Honjo 2002 Tributyltin pollution in coastal areas around northern Kyushu. Jpn. Environ. Toxicol., 5: 43-50 (in Japanese with English abstract)

Inoue, S., S. Abe, Y. Oshima, N. Kai and T Honjo T 2006 Tributyltin contamination of bivalves in coastal areas around northern Kyushu, Japan. Environ. Toxicol., 21: 244-249

Kram, M. L., P. M Stang and P. F. Seligman 1989 Adsorption and desorption of tributyltin in sediments of San Diego and Pearl Harbor. Applied Organometallic Chemistry, 3: 523-536

Kan-Atireklap, S., S. Tanabe and J. Sanguansin 1997 Contamination by butyltin compounds in sediment from Thailand. Mar. Poll. Bull., 34(11): 894-899

Kim, N. S., W.J. Shim, U. H. Yim, S. Y. Ha, J. G. An and K. H. Shin 2011 Three decades of TBT contamination in sediments around a large-scale shipyard. J. Hazardous Materials., 192 634-642

Midorikawa, S., T. Arai, H. Harino, M. Ohji, N. D. Cu and N. Miyazaki 2004 Concentration of organotin compounds in sediment and clams collected from coastal areas in Vietnam. Environ. Poll. 131: 401-408

Miki, S., K. Ikeda, Y. Oba, H. Satone, M. Honda, Y. Shimasaki, N Onikura, O. Arakawa and Y. Oshima 2011 Tributyltin in blood of marine fish collected from a coastal area of northern Kyushu, Japan. Mar. Poll. Bull., 62: 2533-2536

Nirmala, K., Y. Oshima, R. Lee, N. Imada, T. Honjo and K. Kobayashi 1999 Transgenerational toxicity of tributyltin and its combined effects with polychlorinated biphenyls on reproductive processes in japanase medaka (Oryzias latipes). Environ. Toxicol. and Chem., 18(4): 717-721

Ohji, M., T. Arai, S. Midorikawa, H. Harino, R. Masuda and Miyazaki 2007 Distribution and fate of organotin compounds in Japanese coastal waters. Water Air Soil Poll., 178: 255-265

Onduka, T., K. Kono, H. Ichihashi and H. Tanaka 2008 Distribution of organotin compounds in seawaters and sediments in Hiroshima Bay Japan. Environ. Chem., 18(1): 9-17

Page, D. S., C. C. Ozbal and M. E. Lanphear 1995 Concentration of butyltin species in sediments associated with shipyard activity. Environ. Poll., 9(2): 237-243

Rumengan, I. F. M, M., M. Ohji, T. Arai, H. Harino, Z. Arifin and N. Miyazaki 2008 Contamination status of butyltin compounds in Indonesian coastal waters. J. Coast Mar Sci., 32: 116-126

Shim, W. J., J. R. Oh, S. H. Kahng, J. H. Shim and S. H. Lee 1999 Horizontal distribution of butyltins in surface sediments from an enclosed bay system, Korea. Environ. Poll., 106: 351-357

Sudaryanto, A., S. Takahashi, H. Iwata, S. Tanabe and A. Ismail 2004 Contamination of butyltin compounds in Malaysia marine environments. Environ. Poll., 130: 347-358

Sudaryanto, A., S. Takahashi, H. Iwata, T. Shinsuke, M. Muchtar and H. Razak 2005 Organotin residues and the role of anthropogenic tin sources in the coastal marine environment of Indonesia. Mar. Poll. Bull., 50: 208-236 